\title{
Nauja monografija apie Rusijos retrospektyvinę nacionalinę bibliografiją
}

\section{Osvaldas JANONIS}

Vilniaus universiteto Komunikacijos fakulteto Knygotyros ir dokumentotyros institutas, Saulètekio al. 9, LT-10222 Vilnius, el.p.osvaldas.janonis@kf.vu.lt

Retrospektyviné bibliografinè apskaita Rusijoje turi ilga istoriją. Žymiausių rezultatı̆ šiame bare iki Spalio perversmo pasiekè Vasilijus Sopikovas, kuris savo veikale „Rusijos bibliografijos bandymas..." ${ }^{* 1}$ suregistravo leidinius iki XIX a. 3-iojo dešimtmečio pradžios. Vèlesni bandymai parengti rusų knygos repertuara (viseta), kurių èmèsi pavieniai asmenys (G. Genadi, S. Vengerovas ir kt.), kolektyviniai bibliografinès veiklos subjektai (Maskvos bibliografinis ratelis, Rusų bibliografinè draugija), baigési nesėkme. Istorija parodè, kad toki sudètinga uždavini galima išspręsti tik remiant valstybei. $1928 \mathrm{~m}$. Valstybiniai centriniaj knygų rūmai nutare ikurti specialią komisiją bibliografiniam repertuarui parengti. Viešoji biblioteka Leningrade pradèjo perkataloguoti rusų knygu fondą ir leisti spausdintines knygu, išleistų iki 1927 m., katalogo korteles. Tačiau, kaip taikliai pastebi monografijos ${ }^{2}$ autorius, tarybu valstybei nereikèjo išsamios bibliografijos rodyklès, atspindinčios Rusijos istorinio kelio politinę, ideologinę ir kultūrinę ivairovę.

Pedagogikos mokslų kandidatas, Rusijos valstybinès bibliotekos Bibltografijos mokslo sektoriaus vadovas, vienas pagrindiniŁ Rusijos nacionalinès bibliografijos srities specialistu Grigorijus Levinas savo monografijoje detaliai ir kompetentingai nagrinèja Rusijos retrospektyvinès nacionalinès bibliografijos raidą ivairiais istorijos Jaikotarpiais, esmines క̌ios rūšies bibliografijos tcorines, metodologines, organizacines problemas.

Monografija sudaro trys skyriai. Pirmajame skyriuje autorius savo dèmesi sutelkia i retrospektyvinès nacionalines bibliografijos teorines ir metodologines problemas. Antrasis skyrius skirtas šios rūšies bibliografijos Rusijoje teoriniams, metodologiniams, organizaciniams ir valdymo aspektams. Trečiajame skyriuje aptariama spausdintiniu, nepublikuotų ir elektroniniu (skaitmeninių) leidinių retrospektyvinès bibliografinès apskaitos būklê ir raidos perspektyvos.

Ypač vertingas pirmasis monografijos skyrius, kuriame G. Levinas neapsiriboja vien rusų bibliografijos mokslininku požiūriy analize, bet ir pateikia pavyzdžių iš užsieninès praktikos. Jame dar karta akcentuojamas savotiškas paradoksas; nors nacionaliné bibliografija - svarbiausia bibliografijos rūšis, egzistuojanti praktiškai visose pasaulio valstybèse ir sulaukianti teoretikų dèmesio, tačiau pati nacionalinès bibliografijos sq̨voka suprantama labai jvairiai. Autorius laikosi nuomonès, kad tik teritorija ir (arba) kalba teorijos požiūriu gali būti laikomi apskaitos nacionalinéje bibliografijoje požymiais (p. 70). Apskailos objektų analizė leido padaryti išvadą kad jais gali būti: rankraštinès knygos, spausdintinès knygos ir brošjūros, disertaciju autoreferatai, periodiniai ir tęstiniai leidiniai, kartografiniai dokumentiniai ištekliai, natụ dokumentiniai ištekliai, vaizduojamosios dailés spaudiniai, bibliografiniai ištekliai, straipsniai, recenzijos, leidiniai akliesiems, oficialieji leidiniaj ir publikacijos, patentiniai dokumentiniai ištekliai, standartai, mokslo tiriamujju ir bandomujų konstrukcinių darbų ataskaitos, deponuoti rankraščiai, disertacijos, garso dokumentai, vaizdo dokumentai, garso ir vaizdo dokumentai, mikrografiniai dokumentiniai ištekliai, elektroniniai (skaitmeniniai) ištekliai.

Autorius pagrindžia tetrospektyvinès nacionalinès bibliografijos išlekliu sistemą, kurią jo manymu, sudaro: spausdintinès ir elektroninès nacionalinés bibliografijos rodyklès, nacionalinès bibliografijos retrospektyvinès bibliografinių duomenų bazés, spausdintiniai nacionalinés bibliografijos kumuliaciniai leidiniai, kurių chronologinè aprèptis didesnè negu vieneri metai, nacionalinés bibliografijos duomenų integruojamosios bazés (bankai), atnaujinamieji elektroniniai nacionalinès bibliografijos

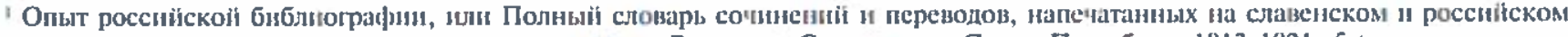

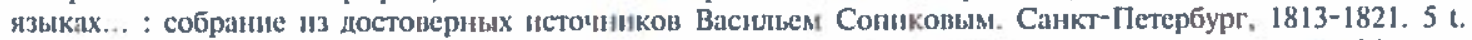

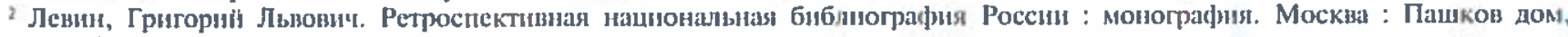
2006. $351,[1]$ p.
} 
leidiniai kompaktiniuose diskuose, nacionalinių spaudos archyvų ir kitų nacionalinių dokumentų fondụ saugyklų katalogai (spausdintiniai ir elektroniniai, integruojamieji arba retrospektyviniai), nacionalinių dokumentų retrospektyviniai suvestiniai katalogai (spausdintiniai ir elektroniniai), nacionaliniai suvestiniai nacionalinių dokumentu katalogairepertuarai (visetai, spausdintiniai ir elektroniniai). Pagrindine forma autorius laiko elektroninę, tačiau ispèja, kad vartotojui šiuo atveju turi būti suteikiama galimybẻ bibliografinius ịrašus rūšiuoti pagal ịvairiausius požymius: autoriu, antraštę, išleidimo vietą ir metus, leidejjo varda, kalbas, dokumentu rūšis, turini, personalijas ir t. t. Jis mano, kad tik tokiu atveju elektroniniai bibliografiniai ištekliai galés realizuoti retrospektyvinès nacionalinès bibliografijos informacinę, komunikacinę ir kultūrinę bei istorinę funkcijas.

Idomios informacijos teikia trečiasis monografijos skyrius, kuriame apibūdinami retrospektyvinès nacionalinès bibliografinès informacijos ištekliai pagal bibliografuojamu dokumentų tipus ir rūšis. Čia aptariami tie bibliografiniai ištekliai, kuriuose registruojami Lietuvos teritorijoje iki Pirmojo pasaulinio karo išleisti leidiniai rusų kalba. Skyrelyje „Lietuvių kalba“ pažymima, kad Lietuvos žemès Rusijos imperijai priskirtos 1795-1810 m. ir kad knygos ir periodiniaj leidiniai iki $1917 \mathrm{~m}$. esą suregistruoti kontroliniuose sąrašuose (tai prasilenkia su tikrove, tačiau bibliografijos leidinių sąraše paminèti ir "Lietuvos TSR bibliografijos“ A serijos „Knygos lietuvių kalba“ du tomai bei pirmojo tomo papildymai. Jame randame ir dvieju "Lietuvos TSR spaudos" tomų aprašą ir atsitiktinai (matyt, dèl kalbos barjero) patekusios Egidijaus Juodžio natu rodyklès „Muzikiné literatūra, 1959-1963“( (1965) aprašq).
Taigi autorius neturẻjo išsamesnès informacijos apie mūsụ nacionalinés bibliografijos leidinių sistemą. Tiesa, jis pamini, kad dabartiniu metu formuojamas Nacionalinès bibliografijos duomenu bankas ir kad Lietuvos bibliografiniai repertuarai aprẻpia viš rūšių spaudinius.

Rusijos retrospektyvinę nacionalinę bibliografiją G. Levinas traktuoja kaip universalios bibliografinès apskaitos sistema, kurios objektas yra Rusijos valstybes, Rusijos nacionaliniu respublikų ir tautu dokumentai. Jis pastebi, kad naudojami ivairūs bibliografinès apskaitos požymiai. Pagrindiniais autorius laiko teritorinị ir kalbinị. Aptardamas teritorini požymị jis akcentuoja, kad bibliografinès apskaitos objektas yra Rusijos valstybès konkrečiose istorinése ribose išleisti dokumentai, nepriklausomai nuo jų kalbos. Rusijos bibliografai realizuoja ir pasaulinio knygų rusu kalba, išleistu 1917-1945 m., repertuaro sudarymo idèja.

Vertinga monografijos dali sudaro 704 bibliografiniu irašų literatūros ir bibliografinių išteklių sąrašas. Tarp cituojamı šaltinių matome ir Lietuvos autoriu vardus (A. Ulpio, V. Lyrovo, V. Žuko, J. Čepytės, O. Janonio).

Taigi recenzuojama monografija yra vertingas inašas $i$ retrospektyvinès nacionalinés bibliografijos tyrimų aruoda. Joje apibendrintas Rusijos bibliografų, dirbančiu universalios retrospektyvinès bibliografinès apskaitos srityje, patyrimas, susumuoti teorinès minties rezultatai, pateikta ne viena rekomendacija, kuri tinka ir mūsu šalies bibliografams. Monografija tarsi primena, kad šių abiejų suvereniu valstybių bibliografai turi sąlyčio tašku ir kad jiems reikia pradèti glaudžiau bendradarbiauti. Kol kas žingsnių link Lietuvos rusiškosios knygos bibliografinès apskaitos dar nežengta. 